\title{
Effect of Salicylic Acid on Biochemical and Physiological Parameters of Two Genotypes of Okra under Salinity Stress
}

\author{
Adewale Michael Esan ${ }^{1, *}$, Charles Ojo Olaiya' ${ }^{1}$, Tolulope Omotope Omolekan², Kamarudeen Adewumi \\ Aremu $^{3}$, Henry Rinde Y. Adeyemi ${ }^{4}$ \\ ${ }^{1}$ Department of Biochemistry, Faculty of Basic Medical Sciences, University of Ibadan, Ibadan, Oyo State, Nigeria. \\ ${ }^{2}$ Department of Biochemistry, Bowen University Iwo, Osun State, Nigeria. \\ ${ }^{3}$ Department of Integrated Sciences, Kwara State College of Education, Oro, Kwara State, Nigeria. \\ ${ }^{4}$ Department of Biochemistry, Federal University of Minna, Niger State, Nigeria.
}

How to cite this paper: Adewale Michael Esan, Charles Ojo Olaiya, Tolulope Omotope Omolekan, Kamarudeen Adewumi Aremu, Henry Rinde Y. Adeyemi. (2020) Effect of Salicylic Acid on Biochemical and Physiological Parameters of Two Genotypes of Okra under Salinity Stress. International Journal of the Science of Food and Agriculture, 4(4), 442-448. DOI: $10.26855 /$ ijfsa.2020.12.011

Received: October 22, 2020

Accepted: November 27, 2020

Published: December 10, 2020

*Corresponding author: Adewale Michael Esan, Department of Biochemistry, Faculty of Basic Medical Sciences, University of Ibadan, Ibadan, Oyo State, Nigeria.

Email: adexphotocopa@yahoo.com

\begin{abstract}
Salinity stress as a major environmental factor negatively impacts plant productivity. A wide range of adaptation strategies is required to overcome this stress. An alternative strategy could be exogenous application of plant growth regulators. The present study was carried out to study the effect of seed pretreatment with salicylic acid on some growth parameters, volatile compounds and antioxidant activity of salt-stressed two genotypes of okra plant. The results of this study showed that the salicylic acid is a valuable biological plant growth regulator that could enhance salt tolerance in okra plant under 50, 100, 150, and 200 $\mathrm{mM} \mathrm{NaCl}$ levels resulting in an increase in plant growth and antioxidant enzymes activities, when compared with the NaCl-treated control groups. Therefore, salicylic acid is a promising tool to improve plant growth and quality under harsh environmental conditions.
\end{abstract}

\section{Keywords}

Okra, Salinity Stress, Salicylic Acid, Antioxidant Enzymes, Growth Parameters

\section{Introduction}

Vast majority of plant species exposed to environmental factors on a daily basis, and among them is the salinity stress. Salinity as abiotic stress constitutes a major threat to agricultural productivity worldwide and usually associated to various biochemical responses such as elevated free radicals content, which invariably leads to oxidative stress [1], with morphological, and physiological changes [2]. When plants root exposed to excess salts in the environment, they produce excessive amounts of reactive oxygen species (ROS) like hydrogen peroxide $\left(\mathrm{H}_{2} \mathrm{O}_{2}\right)$ radicals' superoxide $\left(\mathrm{O}_{2}{ }^{\bullet-}\right)$, and singlet oxygen $\left({ }^{1} \mathrm{O}_{2}\right)$ [3]. During saline conditions, there is high accumulation of $\mathrm{Na}^{+}$and $\mathrm{Cl}^{-}$, which are detrimental factors that may lead to ion imbalance, ion toxicity, and physiological disorder [4]. Salinity significantly affect okra (Abelmoschus esculentus) productivity in arid and semi-arid areas. Okra is a multipurpose crop grown for its fruits and seeds, which have numerous biological properties [5]. Okra growth and productivity affected by salinity as one of its major environmental factors [6].

Various techniques had been put in place to control salinity adverse effects on plants including but are not limited to utilization of transgenic plants and breeding programs [7], chemical priming [8], and salicylic acid [9]. Salicylic acid (SA) is a well-known signaling messenger that plays a pivot role in disease resistance, stress tolerance, and fruit yield [10]. Various studies indicate the ability of exogenous application of SA under saline conditions to increase the accu- 
mulation of osmolytes, enhance antioxidant protection, and maintain optimum $\mathrm{Na}^{+} / \mathrm{K}^{+}$ratio, which is suggested as potential mechanisms of salt tolerance in plants [11-12]. Our previous works indicated that SA minimizes the negative effects of salt stress by improving accumulation of compatible solutes, and increasing antioxidant activity [13-14]. The aim of this study was to investigate the impact of salicylic acid on some key biochemical and physiological parameters in salt-stressed okra.

\section{Materials and Methods}

\subsection{Plant cultivation and Chemical treatments}

Seeds of okra genotypes LD-88 and NHe 47-4obtained from genetic resources Department in National Horticultural Research Institute Ibadan, Nigeria. The seeds were surface sterilized with 1\% sodium hypochloride solution ( $\mathrm{NaOCl})$ for 2 minutes, and finally rinsed with distilled water. Seeds were soaked in a salicylic acid (SA) solution at concentrations of $10^{-2}, 10^{-4}$, and $10^{-6} \mathrm{mM}$ respectively and distilled water to soak the seeds used as control for 24 hours in the dark at $25^{\circ} \mathrm{C}$. Thereafter, the solutions were decanted off and seeds washed 2-3 times with distilled water, and vacuum dried for 1 hour. The seeds $(n=5)$ were then sown in pots containing $10 \mathrm{~kg}$ of soil already treated with 0 (control), 50, 100, 150 , and $200 \mathrm{mM} \mathrm{NaCl}$ solutions. All pots for each genotype were irrigated with normal tap water on weekly basis to achieve soil water field capacity for the period of cultivation. The experiment was in a complete randomize designed and each treatment was replicated three times. Treatments were as follows:

a) Control: 0 (tap water only)

b) Salinity Level (4): 50, 100, 150, and $200 \mathrm{mM} \mathrm{NaCl}$

c) Salicylic acid Level (3): $10^{-2}, 10^{-4}$, and $10^{-6} \mathrm{mM} \mathrm{SA}$

After eight weeks of germination, plant heights $(\mathrm{cm})$ were measured then all plants were harvested. Flag leaf area per plant was measured and the fresh weight (g) was measured then the dry weight (g) was obtained following drying at room temperature $\left(25^{\circ} \mathrm{C}\right)$ according to Elansary and Mahmoud [15]. Plants of each group were collected to investigate the biochemical changes.

\subsection{Growth Parameters}

\subsubsection{Shoot length}

The length measurements were carried out from above soil surface until the end of growing tip of the plants and recorded in centimeters with the aid of meter scale.

\subsubsection{Flag leaf area}

The leaf area $\left(\mathrm{cm}^{2}\right)$ was determined by using the method of Elansary and Mahmoud [15] with the following proposed equation:

$$
\text { Leaf area }=\text { Lenght } \times \text { Breadth } \times 0.75
$$

\subsubsection{Fresh and dry weight of shoot}

Plants from every treatment were weighed immediately after cutting and estimation of the fresh weight of shoot was carried out. The fresh materials were oven dried at $80^{\circ} \mathrm{C}$ to a constant dry weight. The fresh and dry weight of shoot were calculated (Elansary and Mahmoud) [15].

\subsection{Enzyme extractions and assays}

The method described by Tejera et al. [16] was applied to prepare crude enzyme extract. A $1 \mathrm{~g}$ of plant sample was soaked in a buffer solution of potassium phosphate $(0.1 \mathrm{M}, \mathrm{pH}$ 6) with $0.5 \mathrm{mM}$ EDTA. The sample extract was centrifuged at 15,000 rpm for $20 \mathrm{~min}$. The enzymes content of the supernatant was then determined.

\subsubsection{Ascorbate peroxidase assay}

Ascorbate peroxidase activity was estimated according to the method outlined by Yoshimura et al. [17]. The mixture of the reaction contained a buffer solution of potassium phosphate $(50 \mathrm{mM}, \mathrm{pH} 7.0)$ with $0.1 \mathrm{mM}$ of hydrogen peroxide, $0.5 \mathrm{mM}$ ascorbic acid and $200 \mu \mathrm{L}$ of enzyme extract. The mixture was incubated for $5 \mathrm{~min}$ at $25^{\circ} \mathrm{C}$. The activity of ascorbate peroxidasewas measured at $550 \mathrm{~nm}$ using UV/VIS Spectrophotometer. The enzyme activity was expressed as units' $\mathrm{mg}^{-1}$ protein.

\subsubsection{Polyphenol oxidase assay}

Polyphenol peroxidase activity was estimated by using the method of Oktay et al. [18] with slight modifications. The mixture of the reaction contained buffer solution of $0.1 \mathrm{M}$ potassium phosphate at $\mathrm{pH} 6.0$ with enzyme extract $(0.5 \mathrm{~mL})$ and $0.1 \mathrm{M}$ catechol $(1.0 \mathrm{~mL})$. The reaction medium was incubated at $25^{\circ} \mathrm{C}$ for $5 \mathrm{~min}$. After which, $1 \mathrm{~mL}$ of $2.5 \mathrm{~N} \mathrm{H}_{2} \mathrm{SO}_{4}$ was added to stop the reaction. The reading was taken at $495 \mathrm{~nm}$ using UV/VIS Spectrophotometer. 


\subsection{Total flavonoids determination}

The Parket al. [19] method was applied to determine the total flavonoid concentration in the sample. The mixture of the reaction contained $0.15 \mathrm{~mL}$ of $0.3 \mathrm{M}$ aluminium chloride $\left(\mathrm{AlCl}_{3}\right), 0.15 \mathrm{~mL}$ of $0.5 \mathrm{M}$ sodium nitrite $\left(\mathrm{NaNO}_{2}\right), 3.4 \mathrm{~mL}$ of $30 \%$ methanol, and $0.3 \mathrm{~mL}$ of the sample extract. The addition of $1 \mathrm{M}$ sodium hydroxide $(1 \mathrm{~mL})$ was done after 5 min. Incubation was done for about half an hour at $25^{\circ} \mathrm{C}$. Quercetin served as the standard by using its standard curve for determining the flavonoids concentration. Then, the reading was taken at510 $\mathrm{nm}$ using UV/VIS Spectrophotometer

\subsection{Total phenolic determination}

The spectrophotometric method was employed to determine total phenolic content in the sample [20]. Approximately $1 \mathrm{~mL}$ of Folin-ciocalteu's phenol reagent was added to $1 \mathrm{~mL}$ of the sample. A $10 \mathrm{~mL}$ of $7 \% \mathrm{Na}_{2} \mathrm{CO}_{3}$ solution was added to the mixture after $5 \mathrm{~min}$. and thoroughly mixed with distilled water $(13 \mathrm{ml})$ using a magnetic stirrer. The reaction was stored for $90 \mathrm{~min}$ at $25^{\circ} \mathrm{C}$ in the dark. The reading was then taken at $750 \mathrm{~nm}$ using UV/VIS Spectrophotometer. Gallic acid was used as the standard by using its standard curve for determining the phenolic concentration.

\subsection{Statistical analysis}

The data collected were subjected to three-way analysis of variance (ANOVA) using the Statistical Package for the Social Sciences (SPSS). Sample means were compared using Tukey-Kramer multiple comparison procedure at $\mathrm{P}<0.05$.

\section{Results}

\subsection{Growth parameters}

In Tables 1 and 2, it was clearly observed that all morphological aspects of salt-stressed okra genotypes were reduced with increase in salt concentrations. But treatment of okra genotypes with the salicylic acid improved these morphological values above the normal control for both genotypes. The individual concentration of salicylic acid, as well as the combined treatments of salicylic acid with different concentrations of salt stress significantly increased the shoot length, flag leaf area, fresh weight and dry weight values of the two genotypes as compared to both normal and negative controls (Tables 3 and 4).

Table 1. Effect of $\mathrm{NaCl}$ on growth parameters of okra (genotype 47-4)

\begin{tabular}{ccccc}
\hline Treatment $(\mathbf{N a C l}) \mathbf{~ m M}$ & Shoot length $\mathbf{( c m )}$ & Fresh weight $(\mathbf{m g})$ & Dry weight $(\mathbf{m g})$ & Leaf areas $\left(\mathbf{c m}^{2}\right)$ \\
\hline 0 & $37.18 \pm 0.18$ & $13.94 \pm 0.25$ & $2.75 \pm 0.04$ & $150.00 \pm 5.00$ \\
50 & $34.71 \pm 0.07$ & $10.70 \pm 0.05$ & $2.73 \pm 0.02$ & $203.00^{*} \pm 3.51$ \\
100 & $29.50 \pm 0.06$ & $10.51 \pm 0.06$ & $2.66 \pm 0.03$ & $172.00^{*} \pm 1.17$ \\
150 & $28.37 \pm 0.08$ & $9.73^{*} \pm 0.06$ & $2.45 \pm 0.04$ & $125.56 * \pm 1.76$ \\
200 & $21.31^{*} \pm 0.29$ & $9.73^{*} \pm 0.04$ & $2.43^{*} \pm 0.04$ & $54.40^{*} \pm 0.56$ \\
\hline
\end{tabular}

Values are the mean of three replicates mean \pm SE $(n=3)$.

* Significant differences at $\mathrm{P}=0.05$ when compared with normal control.

Table 2. Effect of NaCl on growth parameters of okra (genotype LD 88)

\begin{tabular}{ccccc}
\hline Treatment $(\mathbf{N a C l}) \mathbf{~ m M}$ & Shoot length $(\mathbf{c m})$ & Fresh weight $(\mathbf{m g})$ & Dry weight $(\mathbf{m g})$ & Leaf areas $\left(\mathbf{c m}^{2}\right)$ \\
\hline 0 & $34.99 \pm 0.60$ & $17.22 \pm 0.22$ & $2.51 \pm 0.05$ & $181.82 \pm 1.45$ \\
50 & $31.58 \pm 0.59$ & $10.48^{*} \pm 0.08$ & $2.49 \pm 0.07$ & $175.56 \pm 1.47$ \\
100 & $31.15 \pm 0.31$ & $10.20^{*} \pm 0.10$ & $2.43 \pm 0.04$ & $152.24^{*} \pm 1.50$ \\
150 & $31.10 \pm 0.20$ & $9.91^{*} \pm 0.07$ & $2.42 \pm 0.04$ & $148.00^{*} \pm 2.65$ \\
200 & $28.20^{*} \pm 2.96$ & $9.67^{*} \pm 0.03$ & $2.37^{*} \pm 0.04$ & $83.04^{*} \pm 2.09$ \\
\hline
\end{tabular}

Values are the mean of three replicates mean \pm SE $(n=3)$.

* Significant differences at $\mathrm{P}=0.05$ when compared with normal control.

\subsection{Ascorbate peroxidase activity (APX)}

Table 5 shows a reduction in the ascorbate peroxidase activity with increase concentrations of salinity stress in salt-stressed okra 47-4 genotype. The ascorbate peroxidase activity increased with increase concentration of salinity stress, but with exception of the group treated with 150 and 200mM NaClin LD 88 genotype (Table 6). But under the 
combined effect of salicylic acid and $\mathrm{NaCl}$, the ascorbate peroxidase activity was observed to be steadily increased in a group treated with $10^{-4} \mathrm{mM} \mathrm{SA}$ with exception of the group treated with $200 \mathrm{mMNaCl}$ in genotype $47-4$ (Table 5). In Table 6, increase in ascorbate peroxidase activity was observed in the combined effect of SA and $\mathrm{NaCl}$ in group treated with $10^{-4} \mathrm{mM} \mathrm{SA}$ at 100,150 , and $200 \mathrm{mM} \mathrm{NaCl}$ respectively in LD 88.

Table 3. Effect of SA and NaCl on growth parameters of okra (genotype 47-4)

\begin{tabular}{cccccc}
\hline SA (mM)Treatment & NaCl (mM) & Shoot length(cm) & Fresh weight(mg) & Dry weight $(\mathbf{m g})$ & Leaf areas $\left(\mathbf{c m}^{2}\right)$ \\
\hline & 0 & $39.18 \pm 0.18$ & $13.94 \pm 0.25$ & $3.54 \pm 0.04$ & $150.00 \pm 2.43$ \\
$10^{-2}$ & 50 & $36.68 \pm 0.60$ & $13.42 \pm 0.03$ & $3.54 \pm 0.02$ & $167.33 \pm 2.08$ \\
& 100 & $36.52 \pm 0.03$ & $12.26 \pm 0.03$ & $3.42 \pm 0.02$ & $175.53 \pm 3.84$ \\
& 150 & $31.55 \pm 0.05$ & $11.07 \pm 0.02$ & $3.12 \pm 0.02$ & $176.87 \pm 1.20$ \\
& 200 & $31.00^{*} \pm 0.01$ & $10.33 \pm 0.03$ & $2.53 \pm 0.03$ & $195.74^{*} \pm 1.53$ \\
& 0 & $40.12 \pm 0.18$ & $15.44 \pm 0.05$ & $4.25 \pm 0.02$ & $153.05^{* * \pm 3} \pm 32$ \\
$10^{-4}$ & 50 & $38.48 \pm 0.60$ & $15.12 \pm 0.04$ & $3.72 \pm 0.01$ & $157.35 \pm 2.08$ \\
& 100 & $30.12 \pm 0.05$ & $13.56 \pm 0.01$ & $3.22 \pm 0.03$ & $165.50 \pm 4.04$ \\
& 150 & $30.05 \pm 0.06$ & $11.00 \pm 0.05$ & $2.98 \pm 0.04$ & $180.87 \pm 3.02$ \\
& 200 & $10.00^{*} \pm 0.01$ & $10.43 \pm 0.02$ & $2.47 \pm 0.01$ & $200.74^{*} \pm 5.53$ \\
& 0 & $58.78 \pm 0.38$ & $15.92 \pm 0.05$ & $4.25 \pm 0.02$ & $157.07^{* *} \pm 3.00$ \\
$10^{-6}$ & 50 & $40.00 \pm 0.50$ & $14.45 \pm 0.02$ & $3.72 \pm 0.01$ & $162.25 \pm 2.50$ \\
& 100 & $35.12 \pm 0.05$ & $12.57 \pm 0.03$ & $3.22 \pm 0.03$ & $170.50 \pm 4.25$ \\
& 150 & $32.05 \pm 0.06$ & $12.08 \pm 0.05$ & $2.98 \pm 0.04$ & $183.85 \pm 5.00$ \\
& 200 & $31.08^{*} \pm 0.02$ & $05.75^{*} \pm 0.04$ & $2.47 \pm 0.01$ & $195.74 * \pm 4.45$ \\
\hline
\end{tabular}

Values are means $\pm \mathrm{SE}(\mathrm{n}=3) . *$ and $* *$ Significant differences at $\$ 0.05$ to the positive control, and within negative contr ols with SA respectively determined by Tukey-Kramer multiple range test.

Table 4. Effect of SA and NaCl on growth parameters of okra (genotype LD 88)

\begin{tabular}{cccccc}
\hline SA (mM)Treatment & NaCl (mM) & Shoot length $(\mathbf{c m})$ & Fresh weight $(\mathbf{m g})$ & Dry weight $(\mathbf{m g})$ & Leaf areas $\left(\mathbf{c m}^{2}\right)$ \\
\hline & 0 & $35.20 \pm 0.32$ & $17.42 \pm 0.03$ & $3.67 \pm 0.02$ & $182.15 \pm 4.10$ \\
& 50 & $34.69 \pm 0.14$ & $13.25 \pm 0.02$ & $3.10 \pm 0.01$ & $235.63^{* *} \pm 3.01$ \\
$10^{-2}$ & 100 & $35.52 \pm 0.24$ & $11.27 \pm 0.02$ & $2.58 \pm 0.02$ & $210.33^{* *} \pm 5.50$ \\
& 150 & $31.33 \pm 0.14$ & $11.43 \pm 0.03$ & $2.63 \pm 0.03$ & $175.55 \pm 6.07$ \\
& 200 & $21.02^{*} \pm 0.22$ & $11.27 * \pm 0.02$ & $3.62 \pm 0.02$ & $108.12 \pm 7.05$ \\
& 0 & $44.25 \pm 0.23$ & $18.22 \pm 0.06$ & $4.60 \pm 0.03$ & $205.15 \pm 4.45$ \\
$10^{-4}$ & 50 & $35.35 \pm 0.21$ & $15.20 \pm 0.03$ & $4.10 \pm 0.02$ & $275.74 \pm 7.01$ \\
& 100 & $35.72 \pm 0.13$ & $15.25 \pm 0.05$ & $3.55 \pm 0.03$ & $315.35^{* *} \pm 5.75$ \\
& 150 & $30.33 \pm 0.22$ & $14.40 \pm 0.02$ & $2.75 \pm 0.04$ & $475.65^{* *} \pm 10.07$ \\
& 200 & $20.05^{*} \pm 0.23$ & $14.27 \pm 0.05$ & $2.75 \pm 0.03$ & $385.15^{*} \pm 7.05$ \\
& 0 & $45.35 \pm 0.12$ & $16.40 \pm 0.07$ & $4.55 \pm 0.03$ & $165.05^{* *} \pm 5.00$ \\
$10^{-6}$ & 50 & $35.45 \pm 0.23$ & $12.20 \pm 0.03$ & $3.72 \pm 0.02$ & $152.35 \pm 4.50$ \\
& 100 & $36.34 \pm 0.34$ & $12.17 \pm 0.05$ & $3.25 \pm 0.03$ & $140.55 \pm 4.75$ \\
& 150 & $33.35 \pm 0.27$ & $10.13 \pm 0.04$ & $2.98 \pm 0.04$ & $135.75^{*} \pm 5.05$ \\
& 200 & $25.05 \pm 0.13$ & $07.10^{*} \pm 0.01$ & $2.45 \pm 0.01$ & $130.45^{*} \pm 5.45$ \\
\hline
\end{tabular}

Values are means $\pm \mathrm{SE}(\mathrm{n}=3) . *$ and $* *$ Significant differences at $\mathrm{P} \leq 0.05$ to the positive control, and within negative controls with SA respectively determined by Tukey-Kramer multiple range test.

\subsection{Polyphenol oxidase activity (PPO)}

Salicylic acid had little or no effect on the polyphenol oxidase activity of salt-stressed okra (47-4 and LD 88 genotypes) plant when compared with the normal control and NaCl-treated groups (Tables 5 and 6). However, improved activity of polyphenol oxidase was recorded in genotype LD 88 at different concentrations of salicylic acid under varying concentrations of salinity stress (Table 6).

\subsection{Total flavonoids and phenolic contents}

Tables 5 and 6 show that pre-soaked seeds treatment with salicylic acid had no significant effect $(\mathrm{P}<0.05)$ on total flavonoids and phenolic contents in salt-stressed okra genotypes 47-4 and LD 88 when compared with the normal control and $\mathrm{NaCl}$-treated groups. However, total flavonoids and phenolic contents were increased in the control groups treated with varying concentrations of salicylic acid when compared with the NaCl-treated groups in genotypes 47-4 
and LD 88. But significant increase in total flavonoids and phenolic contents were observed in LD 88 under the group treated with $10^{-4} \mathrm{mM}$ SA at different concentrations of salt stress (Table 6).

Table 5. Effect of SA and NaCl on biochemical parameters of okra (genotype 47-4)

\begin{tabular}{|c|c|c|c|c|c|}
\hline $\begin{array}{l}\text { SA (mM) } \\
\text { Treatment }\end{array}$ & $\begin{array}{l}\mathrm{NaCl} \\
(\mathrm{mM})\end{array}$ & $\begin{array}{c}\text { APX } \\
\text { (units.mg }{ }^{-1} \text { protein) }\end{array}$ & $\begin{array}{c}\text { PPO } \\
\text { (units. } \mathrm{mg}^{-1} \text { protein) }\end{array}$ & $\mathrm{TF}\left(\mathrm{mgQE}^{-1} \mathrm{gdw}\right)$ & $\begin{array}{c}\text { TP (mgGAE } \\
\left.100^{-1} \mathrm{gdw}\right)\end{array}$ \\
\hline \multirow{5}{*}{0} & 0 & $0.31 \pm 0.01$ & $0.38 \pm 0.02$ & $0.24 \pm 0.02$ & $2.92 \pm 0.02$ \\
\hline & 50 & $0.30 \pm 0.01$ & $0.33 \pm 0.01$ & $0.23 \pm 0.01$ & $2.73 \pm 0.01$ \\
\hline & 100 & $0.28 \pm 0.01$ & $0.32 \pm 0.02$ & $0.13 \pm 0.01$ & $2.64 \pm 0.02$ \\
\hline & 150 & $0.29 \pm 0.00$ & $0.23 \pm 0.01$ & $0.12 \pm 0.02$ & $2.64 \pm 0.01$ \\
\hline & 200 & $0.26 \pm 0.02$ & $0.22 \pm 0.01$ & $0.11 * \pm 0.01$ & $2.50 * \pm 0.01$ \\
\hline \multirow{5}{*}{$10^{-2}$} & 0 & $0.40 \pm 0.02$ & $0.39 \pm 0.02$ & $0.25 \pm 0.01$ & $3.06 \pm 0.02$ \\
\hline & 50 & $0.29 \pm 0.00$ & $0.35 \pm 0.01$ & $0.23 \pm 0.02$ & $3.37 \pm 0.01$ \\
\hline & 100 & $0.25 * \pm 0.01$ & $0.34 \pm 0.02$ & $0.22 \pm 0.01$ & $3.17 \pm 0.01$ \\
\hline & 150 & $0.29 \pm 0.00$ & $0.27 \pm 0.01$ & $0.24 \pm 0.02$ & $3.73 \pm 0.02$ \\
\hline & 200 & $0.27 \pm 0.01$ & $0.23 \pm 0.02$ & $0.20 \pm 0.02$ & $3.38 \pm 0.01$ \\
\hline \multirow{5}{*}{$10^{-4}$} & 0 & $0.45 \pm 0.01$ & $0.43 \pm 0.02$ & $0.33 \pm 0.02$ & $3.41 \pm 0.02$ \\
\hline & 50 & $0.32 \pm 0.01$ & $0.37 \pm 0.02$ & $0.35 \pm 0.01$ & $3.94^{* *} \pm 0.01$ \\
\hline & 100 & $0.35 \pm 0.01$ & $0.34 \pm 0.01$ & $0.37 \pm 0.02$ & $3.37 \pm 0.02$ \\
\hline & 150 & $0.36 \pm 0.00$ & $0.33 \pm 0.02$ & $0.37 \pm 0.01$ & $3.38 \pm 0.01$ \\
\hline & 200 & $0.29 \pm 0.01$ & $0.32 \pm 0.01$ & $0.32 \pm 0.01$ & $3.20 * \pm 0.01$ \\
\hline \multirow{5}{*}{$10^{-6}$} & 0 & $0.25 \pm 0.01$ & $0.34 \pm 0.01$ & $0.23 \pm 0.01$ & $3.00 \pm 0.02$ \\
\hline & 50 & $0.31 \pm 0.02$ & $0.33 \pm 0.01$ & $0.18 \pm 0.01$ & $3.17 \pm 0.01$ \\
\hline & 100 & $0.29 \pm 0.02$ & $0.35 \pm 0.02$ & $0.22 \pm 0.02$ & $3.37 \pm 0.01$ \\
\hline & 150 & $0.30 \pm 0.00$ & $0.33 \pm 0.02$ & $0.24 \pm 0.01$ & $2.75^{*} \pm 0.02$ \\
\hline & 200 & $0.27 \pm 0.02$ & $0.32 \pm 0.01$ & $0.17 \pm 0.01$ & $2.30 * \pm 0.01$ \\
\hline
\end{tabular}

Values are means $\pm \mathrm{SE}(\mathrm{n}=3) . *$ and $* *$ Significant differences at $\mathrm{P} \leq 0.05$ to the positive control, and within negative controls with SA respectively determined by Tukey-Kramer multiple range test. Where APX $=$ Ascorbate peroxide, $\mathrm{PPO}=$ Polyphenol oxidase, $\mathrm{TF}=\mathrm{Total}$ flavonoids, $\mathrm{TP}$ = Total phenolic.

Table 6. Effect of SA and NaCl on biochemical parameters of okra (genotype LD 88)

\begin{tabular}{|c|c|c|c|c|c|}
\hline $\begin{array}{c}\text { SA } \\
(\mathrm{mM}) \text { Treatment }\end{array}$ & $\begin{array}{l}\mathrm{NaCl} \\
(\mathrm{mM})\end{array}$ & $\begin{array}{c}\text { APX } \\
\text { (units. } \text { mg }^{-1} \text { protein) }\end{array}$ & $\begin{array}{c}\text { PPO } \\
\text { (units.mg }{ }^{-1} \text { protein) }\end{array}$ & TF(mgQE $\left.E^{-1} g d w\right)$ & $\begin{array}{c}\text { TP(mgGAE } \\
\left.100^{-1} \mathrm{gdw}\right)\end{array}$ \\
\hline \multirow{5}{*}{0} & 0 & $0.40 \pm 0.01$ & $0.45 \pm 0.02$ & $0.27 \pm 0.02$ & $1.90 \pm 0.20$ \\
\hline & 50 & $0.54 \pm 0.10$ & $0.30 \pm 0.01$ & $0.23 \pm 0.01$ & $1.70 \pm 0.50$ \\
\hline & 100 & $0.63 \pm 0.05$ & $0.29 \pm 0.02$ & $0.25 \pm 0.01$ & $1.67 \pm 0.22$ \\
\hline & 150 & $1.26^{*} \pm 0.20$ & $0.21 \pm 0.01$ & $0.25 \pm 0.02$ & $1.64 \pm 0.30$ \\
\hline & 200 & $1.31 * \pm 0.30$ & $0.20 \pm 0.01$ & $0.20 \pm 0.01$ & $1.30 * \pm 0.20$ \\
\hline \multirow{5}{*}{$10^{-2}$} & 0 & $0.41 \pm 0.02$ & $0.49 \pm 0.02$ & $0.26 \pm 0.01$ & $2.35 \pm 0.70$ \\
\hline & 50 & $0.52 \pm 0.04$ & $0.45 \pm 0.01$ & $0.24 \pm 0.02$ & $1.35 \pm 0.51$ \\
\hline & 100 & $0.55 \pm 0.07$ & $0.44 \pm 0.02$ & $0.22 \pm 0.01$ & $1.25 \pm 0.21$ \\
\hline & 150 & $0.29 \pm 0.03$ & $0.47 \pm 0.01$ & $0.24 \pm 0.02$ & $1.23 \pm 0.20$ \\
\hline & 200 & $0.57 \pm 0.02$ & $0.43 \pm 0.02$ & $0.23 \pm 0.02$ & $1.20 * \pm 0.11$ \\
\hline \multirow{5}{*}{$10^{-4}$} & 0 & $0.62 \pm 0.15$ & $0.55 \pm 0.02$ & $0.63 \pm 0.02$ & $3.95 \pm 1.02$ \\
\hline & 50 & $0.69 \pm 0.17$ & $0.45 \pm 0.02$ & $0.60 \pm 0.01$ & $3.94 \pm 0.95$ \\
\hline & 100 & $1.23 * \pm 0.31$ & $0.37 \pm 0.01$ & $0.57 \pm 0.02$ & $3.67 \pm 0.72$ \\
\hline & 150 & $1.32 * \pm 0.20$ & $0.35 \pm 0.02$ & $0.57 \pm 0.01$ & $3.48 \pm 0.61$ \\
\hline & 200 & $1.32 * \pm 0.31$ & $0.34 \pm 0.01$ & $0.52 \pm 0.01$ & $3.40 * \pm 0.01$ \\
\hline \multirow{5}{*}{$10^{-6}$} & 0 & $0.42 \pm 0.02$ & $0.44 \pm 0.01$ & $0.27 \pm 0.01$ & $3.20 \pm 1.02$ \\
\hline & 50 & $0.52 \pm 0.04$ & $0.43 \pm 0.01$ & $0.23 \pm 0.01$ & $3.15 \pm 0.90$ \\
\hline & 100 & $0.55 \pm 0.07$ & $0.43 \pm 0.02$ & $0.23 \pm 0.02$ & $3.10 \pm 1.01$ \\
\hline & 150 & $0.57 \pm 0.03$ & $0.35 \pm 0.02$ & $0.24 \pm 0.01$ & $2.95 * \pm 0.82$ \\
\hline & 200 & $0.58 \pm 0.01$ & $0.30 \pm 0.01$ & $0.17 \pm 0.01$ & $2.35^{*} \pm 0.70$ \\
\hline
\end{tabular}

Values are means $\pm \mathrm{SE}(\mathrm{n}=3) . *$ and $* *$ Significant differences at $\mathrm{P} \leq 0.05$ to the positive control, and within negative controls with SA respectively determined by Tukey-Kramer multiple range test. Where APX = Ascorbate peroxide, $\mathrm{PPO}=$ Polyphenol oxidase, $\mathrm{TF}=\mathrm{Total}$ flavonoids, $\mathrm{TP}$ $=$ Total phenolic. 


\section{Discussion}

It is evident from this study that okra plant growth was significantly inhibited with increasing salinity due to accumulation of salts in plant tissues which reduced vegetative growth. These findings were in tandem with the reports of Shrivastava and Kumar [21] and Gupta and Huang [22]. The increase in shoot length, fresh and dry weights, vegetative growth and overall plant growth of salt-stressed okra plant following SA treatment shows the promising effect of SA during stress conditions. Increased in these physiological parameters show biosynthesis of carbohydrate, which is an indication of osmotic adjustment and stress tolerance in plants. This agrees with the previous observation of Yin et al. [23] who observed carbohydrate accumulation as an indice of osmotic adjustment.

Most biotic and abiotic factors contribute greatly to overproduction of reactive oxygen species (ROS), which invariably result in oxidative stress [24]. Salinity causes oxidative damage through the production of free radicals [25]. Or through alteration of antioxidant molecules levels in plants [25]. Phytotoxic reactions such as lipid peroxidation, protein degradation and DNA mutation are triggered through excessive production of ROS [26]. The first line mechanism against environmental stresses is through antioxidative enzymes. Thus, their activity profiles are essential in the evaluation of tolerance mechanisms. The results showed a significant decrease in ascorbate peroxidase (APX) activity in okra seedling with increasing $\mathrm{NaCl}$ levels, while the activity of polyphenol oxidase (PPO) showed no effect in genotype 47-4. However, in genotype LD 88 at different concentrations of salicylic acid under varying concentrations of salinity stress the increase activity of polyphenol oxidase was recorded. The increase of GSH and ABA synthesis in plant tissues might be responsible for APX and PPO activity in plant tissues. In this present study, mild and high salinity had no effect on both phenolic and flavonoids contents. But treatment with $10^{-4} \mathrm{mM}$ SA concentration improved total flavonoids and phenolic contents of salt-stressed okra plant in genotype LD 88. The increase in phenolic and flavonoids contents in different plant tissues under increasing salinity has also been reported in a number of plants [27].A similar result was also observed by Navarro et al. [28] who reported an increase in total phenolic content in red pepper plants under mild salinity levels.

\section{Conclusion}

In conclusion, our data to some extent revealed that salicylic acid helps okra plant to cope with the deleterious effects of salinity stress. Pretreatment of okra (genotypes 47-4 and LD 88) under salt stress conditions with SA stimulate the salt tolerance of okra plants via improved carbohydrate contents, which is evident in the growth rate. The accumulation of antioxidants, including phenolic and flavonoids, was enhanced by low or moderate levels of salinity but inhibited by severe levels.Thus salicylic acid could be adopted as a potential growth regulator to improve okra plant growth particularly under mild and moderate $\mathrm{NaCl}$ salinity levels. This study will contribute to the sustainability impacts of salicylic acid on okra's resilience to soil salinity.

\section{References}

[1] Acosta-Motos, J. R., Ortuño, M. F., Bernal-Vicente, A., Diaz-Vivancos, P., Sanchez-Blanco, M. J., and Hernandez, J. A. (2017). Plant responses to salt stress: adaptive mechanisms. Agronomy, 7:18. doi: 10.3390/agronomy7010018.

[2] Quan, R., Wang, J., Yang, D., Zhang, H., Zhang, Z., and Huang, R. (2017). EIN3 and SOS2synergistically modulate plant salt tolerance. Sci. Rep., 7:44637. doi: 10.1038/srep44637.

[3] Joseph, B. and Jini, D. (2011). Development of salt tress-tolerant plants by gene manipulation of antioxidant enzymes. Asian Journal of Agricultural Research, (5)1: 17-27.

[4] Gupta, B. and Huang, B. (2014). Mechanism of salinity tolerance in plants: physiological, biochemical, and molecular characterization. Int. J. Genomics. 2014:701596. doi:10.1155/2014/701596.

[5] Fajinmi, A. A. and Fajinmi, O. B. (2010). Incidence of okra mosaic virus at different growthstages of okra plants (Abelmoscluesesculentus (L) under tropical condition. Journal of General and Molecular Virology, 2: 028-031.

[6] Dudley, L. M., Ben-Gal, A., and Shani. U. (2008). Influence of plant, soil and water on the leaching fraction. Vadose Zone Journal, 7: 420-425.

[7] Bhatnagar-Mathur, P., Vadez, V., and Sharma, K. K. (2008). Transgenic approaches for abiotic stress tolerance in plants: retrospect and prospects. Plant Cell Rep., 27: 411-424. doi: 10.1007/s00299-007-0474-9.

[8] Savvides, A., Ali, S., Tester, M., and Fotopoulos, V. (2016). Chemical priming of plants against multiple abiotic stresses: mission possible? Trends Plant Sci., 21: 329-340. doi: 10.1016/j.tplants.2015.11.003.

[9] Fayez, K. A. and Bazaid, S. A. (2014). Improving drought and salinity tolerance in barley by application of salicylic acid and potassium nitrate. J. Saudi Soc. Agric. Sci., 13: 45-55. doi: 10.1016/j.jssas.2013.01.001.

[10] Liu, X., Rockett, K. S., Korner, C. J., and Pajerowska-Mukhtar, K. M. (2015). Salicylicacid signalling: new insights and prospects at a quarter-century milestone. Essays Biochem., 58: 101-113. doi: 10.1042/bse0580101. 
[11] Ashraf, M., Akram, N., Arteca, R., and Foolad, M. (2010). The physiological, biochemical and molecular roles of brassinosteroids and salicylic acid in plant processes and salt tolerance. Critic Rev Plant Sci., 29(3): 162-190.

[12] Hayat, Q., Hayat, S., Irfan, M., Ahmad, A. (2010). Effect of exogenous salicylic acid under changing environment: a review. Environ Exp Bot., 68(1): 14-25.

[13] Esan, A. M., Kabo, M., Felix, A. D., and Charles, O. O. (2017). Comparative effects of indoleacetic acid and salicylic acid on oxidative stress marker and antioxidant potential of okra (Abelmoschus esculentus) fruit under salinity stress. J. Scientia Horticulturae, 216: 278-283.

[14] Esan, A. M. and Olaiya C. O. (2016). Effect of salicylic acid (SA) seeds soaking on the NaCl salt stress-induced changes in soluble sugar and protein accumulation in organs of two genotypes of okra plants. African Journal of Plant Science, 10(6): 105-110.

[15] Elansary, H. O. and Mahmoud, E. A. (2015). Egyptian herbal tea infusions antioxidants and their antiproliferative and cytotoxic activities against cancer cells. Nat. Prod. Res., 29: 474-479. doi: 10.1080/14786419.2014.951354.

[16] Tejera, G. N. A., Olivera, M., Iribarne, C., and Lluch, C. (2004). Partial purification and characterization of a non-specific acid phosphatase in leaves and root nodules of Phaseolus vulgaris. Plant Physiology and Biochemistry, 42: 58-65.

[17] Yoshimura, K., Yabuta, Y., Ishikawa, T., and Shigeoka, S. (2000). Expression of spinach ascorbate peroxidase isoenzymes in response to oxidative stresses. Plant Physiolog Journal, 123: 223-234.

[18] Oktay, M., Küfrevioçlu, I., Kocaçalýpkan, I., and Pakiroçlu, H. (1995). Polyphenoloxidase from Amasya apple. Journal of Food Science, 60(3): 494-496.

[19] Park, Y. S., Jung, S. T., Kang, S.G., Heo, B. K., Arancibia-Avila, P., Toledo, F., Drzewiecki, J., Namiesnik, J., and Gorinstein, S. (2008). Antioxidants and proteins in ethylene treated Kiwifruits. Food Chemistry, 107: 640-648.

[20] Kim, D., Chun, Y., Kim, H., and Lee, C. (2003). Quantification of phenolic and their antioxidant capacity in fresh plums. Journal of Agriculture Food Chemistry, 5: 6509-6515.

[21] Shrivastava, P. and Kumar, R. (2015). Soil salinity: a serious environmental issue and plant growth promoting bacteria as one of the tools for its alleviation. Saudi J. Biol. Sci., 22: 123-131. doi: 10.1016/j.sjbs.2014.12.001.

[22] Gupta, B. and Huang, B. (2014). Mechanism of salinity tolerance in plants: physiological, biochemical, and molecular characterization. Int. J. Genomics, 2014: 701596. doi: 10.1155/2014/701596.

[23] Yin, Y. G., Kobayashi, Y., Sanuki, A., Kondo, S., Fukuda, N., Ezura, H., et al. (2010). Salinity induces carbohydrate accumulation and sugar-regulated starch biosynthetic genes in tomato (Solanum lycopersicum L. cv. 'Micro-Tom') fruits in an ABAand osmotic stress-independent manner. J. Exp. Bot., 61: 563-574. doi: 10.1093/jxb/erp333.

[24] Essa, A. M. (2012). Effect of continuous mercury stress on mercury reducing community of some characterized bacterial strains. Afr. J. Microbiol. Res., 6(6): 255-1261.

[25] Karuppanapandian, T., et al. (2011). Reactive oxygen species in plants: their generation, signal transduction, and scavenging mechanisms. AJCS., 5(6): 709-725.

[26] Rady, M. M. and Hemida, A. K. (2016). Sequenced application of ascorbate-proline-glutathione improves salt tolerance in maize seedlings. Ecotoxicol. Environ. Safety, 133: 252-259.

[27] Muthukumarasamy, M., Gupta, S. D. and Pannerselvam, R. (2000). Enhancement of peroxidase, polyphenol oxidase and superoxide dismutase activities by tridimefon in NaCl-stressed Raphanussativus L. Biology of Plant, 43: 317-320.

[28] Navarro, J. M., Flores, P., Garrido, C., and Martinez, V. (2006). Changes in the contents of antioxidant compounds in pepper fruits at ripening stages, as affected by salinity. Food Chemistry, 96: 66-73. 